\title{
Optimizing Plant Density for Promising Castor Hybrid DCH 519
}

\author{
P. Kathirvelan* \\ Tapioca and Castor Research Station, Tamil Nadu Agricultural University, P.G. Palayam, \\ Yethapur - 636 119, Salem, Tamil Nadu, India \\ *Corresponding author
}

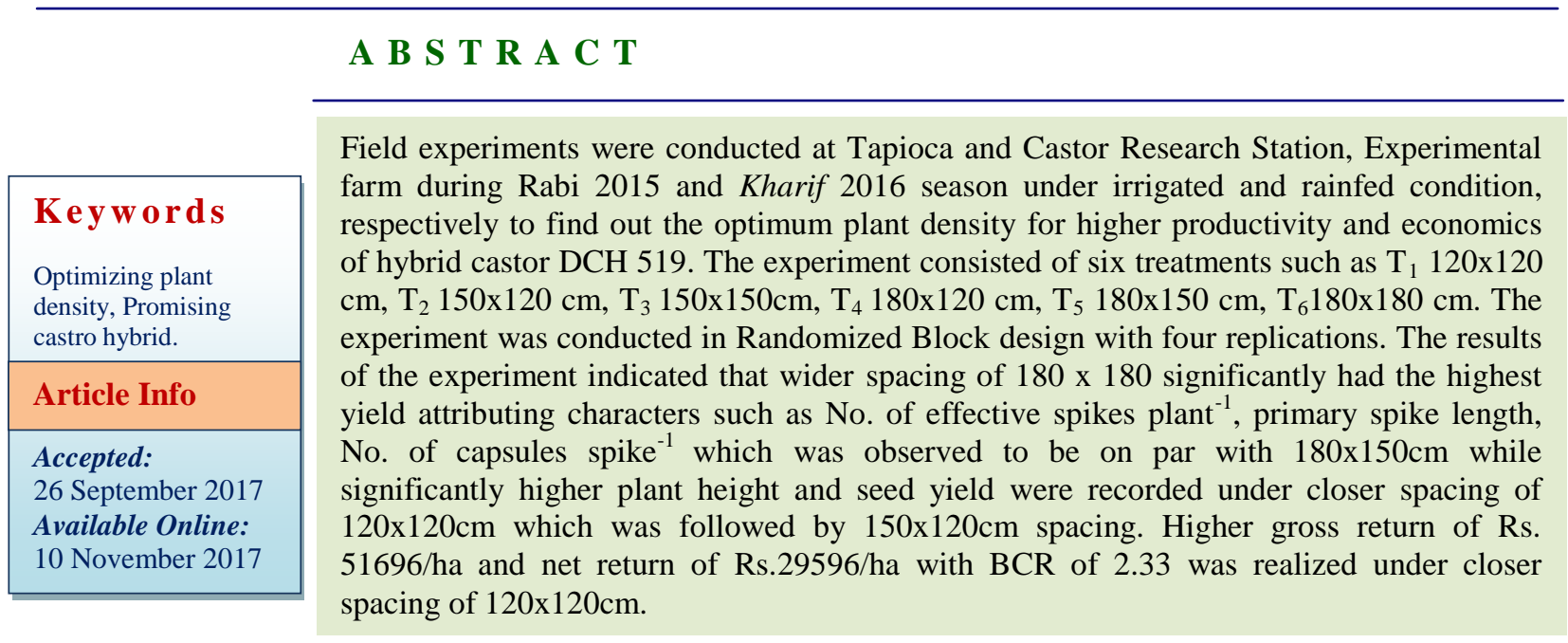

\section{Introduction}

Castor is one of the ancient and commercially very important industrial and non-edible oil crop in the world. It has the ability to grow under low rainfall and fertility conditions, and is most suitable for dryland farming. The oil content of the seeds varies from $50-55 \%$ in different hybrids and varieties. The importance of oil arises from its richness of ricinolic acid (85-95\%) which has number of uses in several industries. That is the reason why castor has steady and staple market price across the country and throughout the period. Thus, castor is largely grown as rainfed crop under wide range of soil and climatic condition. One of the critical factors limiting yield of castor hybrid is inadequate plant density. The optimization of row spacing and in-row plant density is a simple procedure with a low cost but has a significant influence on yield (Soratto et al., 2012) and is essential to maximize seed production. In fact, one of the major reasons for low productivity in hybrid castor in India is due to the maintenance of inadequate plant population and poor fertility management. A proper utilization of inter row spacing for rising inter crop with optimum plant density is necessary to enhance the system productivity. Optimizing planting population is an inexpensive practice that can significantly increase castor seed yield. However, the optimum plant population varies influenced 
by the genotype, environmental conditions and agricultural practices. Because environmental conditions are not constant, there is not an individual plant density that can be broadly recommended for castor (Severino et al., 2006d). Castor exhibits considerable plasticity to spacing variation and available research data indicated that castor hybrid performs better in terms of seed yield and quality when sown under optimum plant density. Adoption of wider spacing is beneficial in reducing the severity of botrytis disease, while in highly fertile soils with adequate water facilities, wider spacing can result in the lush growth of castor, leading to plant lodging, hindering all agronomic management practices including harvesting. Thus, plant density plays a pivotal role in influencing the seed yield. Castor exhibits considerable plasticity to spacing variation and available research data indicated that castor hybrid performs better in terms of seed yield and quality when sown under optimum plant density. Considering all facts, the experiment was conducted to standardize optimum plant density for productivity enhancement of DCH 519 both under rainfed and irrigated ecosystem.

\section{Materials and Methods}

To find out the optimum plant density for higher productivity and economics of hybrid castor DCH 519, field experiments were conducted at Tapioca and Castor Research Station, Experimental farm during Rabi 2015 and Kharif 2016 season under irrigated and rainfed condition, respectively with the following treatments such as $T_{1} 120 \times 120 \mathrm{~cm}$, $\mathrm{T}_{2} 150 \times 120 \mathrm{~cm}, \mathrm{~T}_{3} 150 \times 150 \mathrm{~cm}, \mathrm{~T}_{4} 180 \times 120$ $\mathrm{cm}, \mathrm{T}_{5} 180 \times 150 \mathrm{~cm}, \mathrm{~T}_{6} 180 \times 180 \mathrm{~cm}$. The experiment was conducted in Randomized Block design with four replications. The soil of the experimental field indicates red sandy loam with non-calcareous type and available nutrient status of the experimental site was low in N \& $\mathrm{P}\left(262\right.$ and $\left.5.10 \mathrm{~kg} \mathrm{ha}^{-1}\right)$ and high in $\mathrm{K}\left(355 \quad \mathrm{~kg} \mathrm{ha}^{-1}\right)$. The germination percentage of seed was more than 90 per cent and the required plant population per unit area as per the treatment was maintained with gap filling done within 10 days after sowing. Farm yard manure@ $12.5 \mathrm{t} \mathrm{ha}^{-1}$ was applied commonly to all the treatments. A fertilizer schedule of 60:30:30 kg N, $\mathrm{P}_{2} \mathrm{O}_{5}$ and $\mathrm{K}_{2} \mathrm{O} \mathrm{ha}^{-1}$ were kept constant for all the treatments and were applied along the planting rows as urea, DAP and Muriate of Potash and covered with soil. All other plant protection measures were adopted as per the technical programme.

\section{Results and Discussion}

\section{Seasonal Variation (Rabi 2015 and Kharif 2016)}

In general, irrespective of the treatment effects, the crop performed better during Rabi 2015 season as compared to Kharif 2016 season. Higher seed yield obtained in Rabi 2015 season might be due to favourable weather parameters that prevailed and this might have impressed yield attributes. Favourable mean maximum and minimum temperature of 29.7 and $22.0^{\circ} \mathrm{C}$, respectively, mean relative humidity of 85.6 per cent with rainfall of $374 \mathrm{~mm}$ during the crop growing periods invigorated yield and yield attributing characters which reflected on improved yield components. This resulted in higher seed yield of $2310 \mathrm{~kg} \mathrm{ha}^{-1}$ during Rabi 2015 season under closer spacing of $120 \times 120 \mathrm{~cm}$. On the other hand, during Kharif 2016 season, low rainfall coupled with high temperature and continuous dry spell impaired the physiological activity of the crop and thus affected yield components and hence comparatively lower seed yield was obtained. Between the two seasons studied growth, yield attributing characters and seed yield were more during Rabi 2015 season than that of Kharif 2015 season. 
Table.1 Growth and yield attributing characters of castor hybrid DCH 519 as influenced by plant density during 2015 and 2016 seasons

\begin{tabular}{|c|c|c|c|c|c|c|}
\hline \multirow{2}{*}{ Treatment } & \multicolumn{2}{|c|}{ Plant height $(\mathrm{cm})$ at harvest } & \multicolumn{2}{|c|}{ Days to $50 \%$ flowering } & \multicolumn{2}{|c|}{ No. of effective spikes/plant } \\
\hline & Rabi 2015 & Kharif 2016 & Rabi 2015 & Kharif 2016 & Rabi 2015 & Kharif 2016 \\
\hline $\mathrm{T}_{1} 120 \times 120 \mathrm{~cm}$ & 121.4 & 86.2 & 65 & 68 & 9.5 & 6.9 \\
\hline $\mathrm{T}_{2} 150 \times 120 \mathrm{~cm}$ & 117.7 & 84.0 & 64 & 67 & 9.9 & 7.2 \\
\hline $\mathrm{T}_{3} 150 \times 150 \mathrm{~cm}$ & 114.6 & 74.7 & 65 & 67 & 10.9 & 8.8 \\
\hline $\mathrm{T}_{4} 180 \times 120 \mathrm{~cm}$ & 115.5 & 82.2 & 65 & 67 & 10.2 & 8.5 \\
\hline $\mathrm{T}_{5} 180 \times 150 \mathrm{~cm}$ & 112.2 & 73.8 & 64 & 68 & 11.4 & 10.1 \\
\hline $\mathrm{T}_{6} 180 \times 180 \mathrm{~cm}$ & 111.3 & 71.3 & 65 & 68 & 12.8 & 10.6 \\
\hline SEd & 7.10 & 5.07 & 0.75 & 0.75 & 1.46 & 1.37 \\
\hline $\mathrm{CD}(\mathrm{p}=0.05)$ & 14.92 & 10.66 & 1.59 & 1.58 & 3.07 & 2.88 \\
\hline
\end{tabular}

Table.2 Yield attributing characters of castor hybrid DCH 519 as influenced by plant density during 2015 and 2016 seasons

\begin{tabular}{|c|c|c|c|c|c|c|}
\hline \multirow{2}{*}{ Treatment } & \multicolumn{2}{|c|}{ Length of primary spike (cm) } & \multicolumn{2}{|c|}{ No. of capsules/spike } & \multicolumn{2}{|c|}{ Test weight } \\
\hline & Rabi 2015 & Kharif 2016 & Rabi 2015 & Kharif 2016 & Rabi 2015 & Kharif 2016 \\
\hline $\mathrm{T}_{1} 120 \times 120 \mathrm{~cm}$ & 60.1 & 56.7 & 84.5 & 65.6 & 26.5 & 24.8 \\
\hline $\mathrm{T}_{2} 150 \times 120 \mathrm{~cm}$ & 62.6 & 57.4 & 88.2 & 73.4 & 26.4 & 25.0 \\
\hline $\mathrm{T}_{3} 150 \times 150 \mathrm{~cm}$ & 68.5 & 60.2 & 92.7 & 81.2 & 26.6 & 25.1 \\
\hline $\mathrm{T}_{4} 180 \times 120 \mathrm{~cm}$ & 66.7 & 58.1 & 90.5 & 79.8 & 26.5 & 24.9 \\
\hline $\mathrm{T}_{5} 180 \times 150 \mathrm{~cm}$ & 72.3 & 61.0 & 95.4 & 88.7 & 26.5 & 25.1 \\
\hline $\mathrm{T}_{6} 180 \times 180 \mathrm{~cm}$ & 75.2 & 62.5 & 98.3 & 89.5 & 26.9 & 25.2 \\
\hline SEd & 4.67 & 4.10 & 5.96 & 5.51 & 0.85 & 0.85 \\
\hline $\mathrm{CD}(\mathrm{p}=0.05)$ & 9.81 & 8.62 & 12.52 & 11.56 & 1.78 & 1.79 \\
\hline
\end{tabular}

Table.3 Seed yield and economics of castor hybrid DCH 519 as influenced by plant density during 2015 and 2016 seasons

\begin{tabular}{|c|c|c|c|c|c|c|c|c|}
\hline \multirow{2}{*}{ Treatment } & \multicolumn{2}{|c|}{ Seed yield (kg/ha) } & \multicolumn{2}{|c|}{ Cost of cultivation (Rs/ha) } & \multicolumn{2}{|c|}{ Net return (Rs/ha) } & \multicolumn{2}{|c|}{ BCR } \\
\hline & Rabi 2015 & Kharif 2016 & Rabi 2015 & Kharif 2016 & Rabi 2015 & Kharif 2016 & Rabi 2015 & Kharif 2016 \\
\hline $\mathrm{T}_{1} 120 \times 120 \mathrm{~cm}$ & 2310 & 1426 & 26950 & 22100 & 56210 & 29236 & 3.08 & 2.32 \\
\hline $\mathrm{T}_{2} 150 \times 120 \mathrm{~cm}$ & 2147 & 1355 & 26850 & 22000 & 50442 & 26780 & 2.88 & 2.22 \\
\hline $\mathrm{T}_{3} 150 \times 150 \mathrm{~cm}$ & 2039 & 1382 & 26800 & 21950 & 46604 & 27802 & 2.74 & 2.27 \\
\hline $\mathrm{T}_{4} 180 \times 120 \mathrm{~cm}$ & 1828 & 1237 & 26800 & 21950 & 39008 & 22582 & 2.46 & 2.03 \\
\hline $\mathrm{T}_{5} 180 \times 150 \mathrm{~cm}$ & 1948 & 1257 & 26650 & 21800 & 43478 & 23452 & 2.63 & 2.08 \\
\hline $\mathrm{T}_{6} 180 \times 180 \mathrm{~cm}$ & 1895 & 1271 & 26650 & 21800 & 41570 & 23956 & 2.56 & 2.10 \\
\hline SEd & 113.4 & 73.1 & - & - & - & - & - & - \\
\hline $\mathrm{CD}(\mathrm{p}=0.05)$ & 238.4 & 154 & - & - & - & - & - & - \\
\hline
\end{tabular}


Among different plant density evaluated, plant height differed markedly at harvest. Closer spacing of $120 \times 120$ was found superior over other plant density during both seasons though it was at par with $120 \times 150 \mathrm{~cm}$. Plant density did not have any significant influence on days to fifty percent flowering during both the seasons of study (Table 1).

Effect of plant density on growth, yield attributes and yield of castor hybrid DCH 519

Plant population had a significant influence on the growth and yield attributing characters of castor as evidenced from the results of the experiment. During both the season, wider spacing of $180 \mathrm{x}$ 180 significantly had the highest yield attributing characters such as No. of effective spikes plant ${ }^{-1}$, primary spike length, No. of capsules spike ${ }^{-1}$ which was observed to be on par with $180 \times 150 \mathrm{~cm}$. As the feeding zone of castor hybrid per plant under wider spacing is more when compared to closer spacing, the plants grew laterally and resulted in higher number of productive branches plant $^{-1}$ (Table 2). Similar findings are in accordance with Kathirvelan et al., (2006). The better yield attributing characters in wider row spacing $(180 \times 180 \mathrm{~cm})$ was mainly due to sufficient space between rows which encouraged to produce more vigorous plants and also lesser interplant competition for space, light, nutrient and moisture and resulted in more source to sink movement and partitioning efficiency. The reduction in other yield attributing characters viz., seed yield and haulm yield in wider row spacing of $180 \times 180 \mathrm{~cm}$ was associated with lower plant population load per unit area.

Significantly higher plant height was recorded under closer spacing of $120 \times 120 \mathrm{~cm}$ which was followed by $150 \times 120 \mathrm{~cm}$ spacing. No significant difference was observed among the plant densities with respect to days to fifty percent flowering because this parameter is mainly governed by the genetic makeup of the plants. Though the yield attributes like No. of effective spikes plant ${ }^{-1}$, primary spike length and No. of capsules spike ${ }^{-1}$ were increased significantly with lower plant population of 3086 plants $\mathrm{ha}^{-1}(180 \times 180 \mathrm{~cm})$, castor seed yield was significantly higher (1436 $\mathrm{kg} \mathrm{ha}^{-1}$ ) with a higher population level of 6944 plant ha ${ }^{-1}(120 \times 120 \mathrm{~cm})$ which was observed to be on par with $150 \times 120 \mathrm{~cm}\left(1355 \mathrm{~kg} \mathrm{ha}^{-1}\right)$. This was mainly due to increased population load per unit area. With respect to economics, higher gross return of Rs. 51696/ha and net return of Rs.29596/ha with BCR of 2.33 was realized under closer spacing of $120 \times 120 \mathrm{~cm}$ (Table 3 ). From this study, it could be concluded that closer spacing of $120 \times 120 \mathrm{~cm}$ had recorded significantly higher yield attributing characters and seed yield with higher monitory returns.

\section{References}

Guilherme Eugenio Machado Lopes, Henrique Duarte Vieira and Fabio Luiz Partelli. 2013. Response of Castor Bean Plants to Different Row Spacings and Planting Seasons. American Journal of Plant Sciences, 2013, 4, 10-15.

Kathirvelan, P., and P. Kalaiselvan.2006. Growth Characters, Physiological Parameters, Yield Attributes and Yield as Influenced by the Confectionery Groundnut Varieties and Plant Population. Research Journal of Agriculture and Biological Sciences, 2(6): 287-291.

Severino, L.S., C.R.A. Moraes, T.M.S. Gondim, G.D. Cardoso, and N.E.M. Beltrao. 2006d. Yield of castor planted at different row space. Revista Ciencia Agronomica 37:5054.

Soratto, R. P, Souza-Schlick, G. D, Fernandes, A. M, Zanotto, M. D, Crusciol, C. A. C. Narrow row spacing and high plant population to short height castor genotypes in two cropping seasons. Industrial Crops and Products, V. 35, N. 1, p. 244-249.

\section{How to cite this article:}

Kathirvelan, P. 2017. Optimizing Plant Density for Promising Castor Hybrid DCH 519. Int.J.Curr.Microbiol.App.Sci. 6(11): 3694-3697. doi: https://doi.org/10.20546/ijcmas.2017.611.432 